\title{
A comparative interdisciplinary study of gilding techniques and materials in two Portuguese Baroque "talha dourada" complexes
}

\author{
I.C.A. Sandu, E. Murta, E. R. Neves, M.F.C. Pereira, A. V. Sandu, \\ S. Kuckova, A. Maurício
}

\begin{abstract}
The gilded polychrome carved wood in Portugal, (talha dourada) gained its most rich expression during the Baroque epoch with the development of production techniques and the use of of gold leaf. The present paper proposes a complementary and comparative study of two important complexes of talha: one from St. Alberto's church, integrating the visiting circuit of the Museu Nacional de Arte Antiga (Lisbon), and the other from church of Vale de Figueira (Santarém district). Both complexes house talha dourada's decoration from the 18th century, that were studied through an inter-disciplinary approach, in which analytical data (optical microscopy, fluorescent stain, XRF, SEM-EDX, micro-computerized tomography, FTIR, Matrix-Assisted Laser Desorption/Ionisation-Time of Flight Mass Spectrometry) complement historical data.
\end{abstract}

\section{Keywords:}

carved gilded wood, comparative study, gilding techniques, materials, analytical study.

\section{Um Estudo Comparativo Interdisciplinar das Técnicas e Materiais de Douramento em dois conjuntos de talha dourada barrocos portugueses.}

\section{Resumo}

A arte da talha dourada em Portugal ganhou a sua mais rica expressão durante a época barroca devido ao desenvolvimento das técnicas de produção e ao uso do ouro em folha. O presente trabalho propõe um estudo complementar e comparativo de dois complexos importantes da talha respectivamente em Lisboa, na Igreja de São Alberto, integrada no circuito de visitas do Museu Nacional de Arte Antiga, e no distrito de Santarém, na Igreja de Vale de Figueira. Os dois complexos albergam decoração em talha dourada do século XVIII, estudados através de uma abordagem inter-disciplinar, em que os dados analíticos (microscopia óptica, teste de coloração fluorescente, FRX, MEV-EDX, microtomografia computadorizada, FTIR, Matrix-Assisted Laser Desorption/Ionisation-Time of Flight Mass Spectrometry) complementam os dados históricos.

\section{Palavras-chave:}

"talha dourada", estudo comparativo, técnica de douramento, materiais, estudo analítico. 
A comparative interdisciplinary study of gilding techniques and materials in two Portuguese Baroque "talha dourada" complexes

I.C.A. Sandu, E. Murta, E. R. Neves, M.F.C. Pereira, A. V. Sandu, S. Kuckova, A. Maurício

\section{Un Estudio Comparativo e Interdisciplinar de las Técnicas y Materiales de Dorado en dos Conjuntos de Talla Dorada del Barroco Portugués.}

\section{Resumen}

El arte de la talla dorada en Portugal ganó su más rica expresión durante el período barroco a través del desarrollo de técnicas de producción y el uso de pan de oro. Este trabajo propone un estudio complementario y comparativo de dos grandes complejos de talla, el de la Iglesia de San Alberto, integra el circuito de visita del Museu Nacional de Arte Antiga en Lisboa, y el de la Iglesia de Vale Figueira, en Santarém. Los dos complejos albergan retablos dorados del siglo XVIII, que han sido estudiados a través de una metodología interdisciplinar, en la que los datos analíticos (microscopia óptica, tinción fluorescente, fluorescencia de rayos X, SEM-EDX, micro-tomografía computerizada, FTIR, MALDI-TOF-MS) complementan los datos históricos.

\section{Palabras clave:}

"talla dorada", estudio comparativo, técnica de dorado, materiales, estudio analítico.

\section{Introduction}

The cultural heritage of Portugal includes different typologies of decorative wooden gilded polychrome art-objects testifying a long evolution of gilding techniques namely from the late Renaissance period to Baroque epoch, roughly between 1500 and 1800 . A decorative phenomenon, called "talha dourada", has been adopted and largely used, together with other artistic techniques such as "azulejos", in a form of a total work of art, as an expression of a national mark, religious faith and catechetical message vehicle [1-10]. Although subjected to intensive historical research [1-4], "talha dourada" decorations all over the Portuguese territory were not systematically investigated from the material and technical points of view, therefore many churches and museums house today altarpieces, retables and other wooden and gilded decorations, never studied. Only punctual information speaking of the conservation and restoration interventions performed on some national altarpieces with gilded decorations was reported [5-16]. Gilded decoration on wooden support has been extensively studied not only in Europe but also in other places, as in North and South America [17-21]. Therefore a comparative study with other similar objects and/or gilding layers would be necessary to increase the knowledge on these works of art.

Two important complexes of "talha" from two churches - the Chapel of Albertas in Lisbon, now part of the Museu Nacional de Arte Antiga (National Museum of Ancient Art) (Fig. 1) and the Church of Vale de Figueira nearby Santarém (Fig. 2), both carved and assembled during the $18^{\text {th }}$ century, were studied through an inter-disciplinary and multi-scale approach. 
A comparative interdisciplinary study of gilding techniques and materials in two Portuguese Baroque "talha dourada" complexes

I.C.A. Sandu, E. Murta, E. R. Neves, M.F.C. Pereira, A. V. Sandu, S. Kuckova, A. Maurício

The church of Saint Albert, or of Albertas as it is normally called, was part of the extinct Discalced Carmelite Convent in Lisbon. Nowadays, it integrates the National Museum of Ancient Art (MNAA), being the only building that has survived from the former convent of St. Albert after the Lisbon's earthquake in 1755 [11-12]. Its interior was rebuilt in a late Baroque style, (called in Portuguese "Joanino" style) during the reign of the King D. João V [1-2]. The wooden carved decoration in the lateral and main altarpieces followed a decorative program with characteristic pseudo-solomon columns, of "national" style, large windings of acanthus, phoenixes, vine leafs and grapefruits, typical of the late "Joanino" baroque style, already mixed with Rococo lambrequin and seashell motifs. This church houses one of the most beautiful and complex decoration conjugating large descriptive panels of "azulejos" and wooden carved "talha dourada" characteristic to the Portuguese baroque in a "total art" concept decoration. This ornamentation was subject to conservation, cleaning and consolidation interventions in 1982 and 1994 [12].

Another church, built during $17^{\text {th }}-18^{\text {th }}$ centuries, is S. Domingos church in Santarém (Vale de Figueira, VF), housing a smaller, but not less significant, complex of "talha dourada". The main altarpiece as well as the side chapels altarpieces were made on the first quarter of the $18^{\text {th }}$ century, and they are representative of the Portuguese "talha dourada" style, including Eucharistic throne, lateral mouldings and valances of the side doors. Before starting restoration interventions in the summer of 2009 , several gilded samples were taken from this complex.

The conservation state of the gilded layers is generally good for both complexes, losses of cohesion and adhesion, in some areas and deposition of dirt and atmospheric particles are visible. The most urgent problems to be solved in the Saint Albert church are due to the lack of consistency of the plaster walls, which affects the altarpiece's structural stability, and to the fluctuations of climatic parameters, such as relative humidity (RH) and temperature $(T)$, registered inside the church throughout the year. The wooden ceiling and the left wall of the nave, in direct contact with the exterior, were subject to rainwater infiltration and environmental problems that caused constant detachments of gilded carved details [12]. 
A comparative interdisciplinary study of gilding techniques and materials in two Portuguese Baroque "talha dourada" complexes

I.C.A. Sandu, E. Murta, E. R. Neves, M.F.C. Pereira, A. V. Sandu, S. Kuckova, A. Maurício

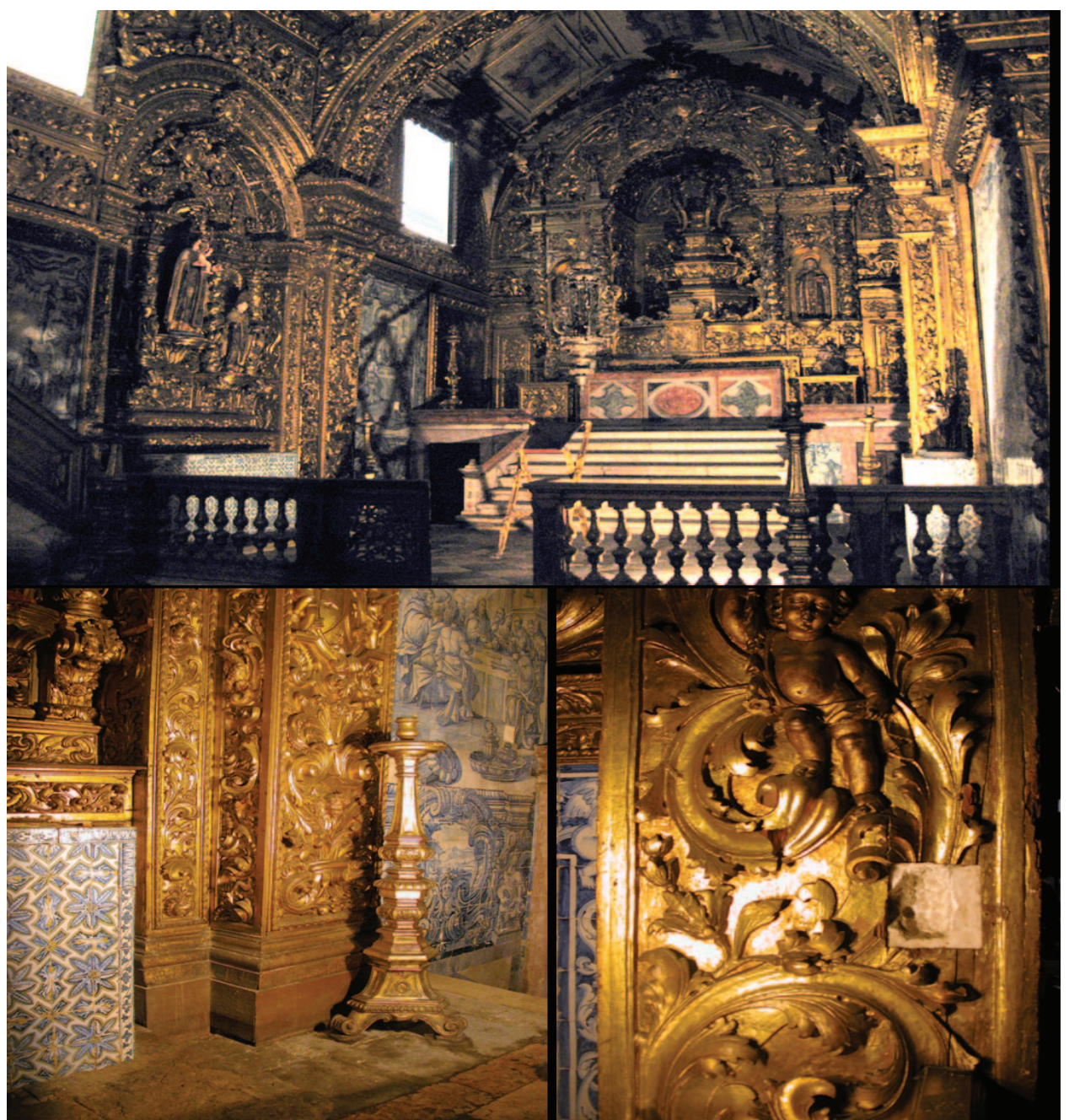

Figure 1. View and details of the complex of "talha dourada" from St. Albert church in Lisbon

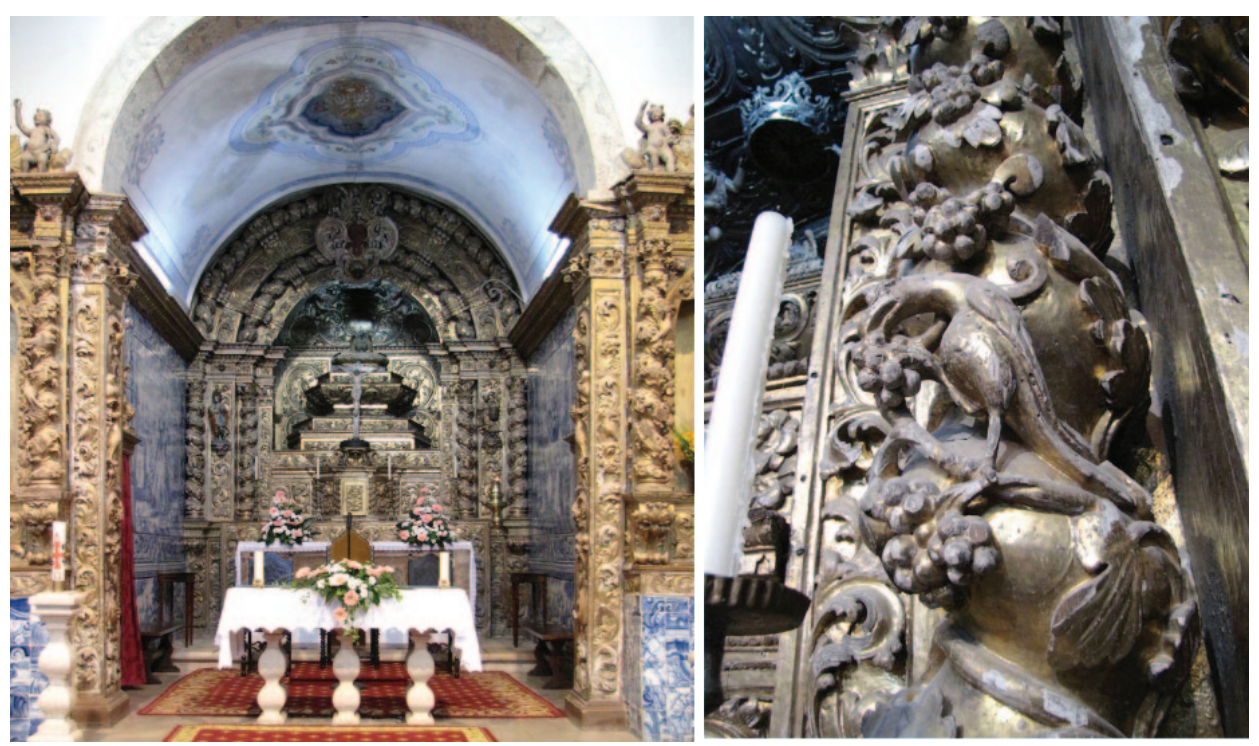

Figure 2. View and detail of the complex of "talha dourada" from Vale de Figueira 
A comparative interdisciplinary study of gilding techniques and materials in two Portuguese Baroque "talha dourada" complexes

I.C.A. Sandu, E. Murta, E. R. Neves, M.F.C. Pereira, A. V. Sandu, S. Kuckova, A. Maurício

In the Saint Albert church all the carved, gilded and polychrome decorations, mainly in Pinus silvestris, sp. wood, were subject to conservation interventions on two occasions, in 1982 and in 1994. Consolidation interventions were performed using the wax-resin method (virgin wax and dammar resin in ratio of 7:2, hot melt with addition of an aromatic solvent). This treatment has the advantage to be easily implemented "in situ" and to be reactivated by the application of heat or by the use of organic solvents at any time. Another intervention campaign should be prepared and a methodology must be evaluated.

In the case of S. Domingos church, the restoration interventions in the summer of 2009 aimed to re-establish the integrity of the polychrome gilded decoration of the altar and to consolidate the original parts.

The study of these two "talha dourada" complexes aimed to:

- characterize the structure and manufacture technique of the gilding stratigraphy;

- identify the chemical composition of each layer constituting the gilded polychrome decoration (from the ground to the final finishing varnish or glaze);

- map the distribution of organic binders or varnishes in the stratigraphical structure of the polychrome composites;

- better understand the effects of a consolidation treatment using wax-resin (7:2) system applied in the case of MNAA gilded decoration.

Few analytical data on the stratigraphic structure and composition of layers in samples from the Church of Albertas were already available from a previous study [12].

The different analytical techniques proposed for this study create a novel complementary approach by using optical microscopy (OM) and scanning electron microscopy-energy dispersive X-ray spectrometry (SEM-EDX), X-ray fluorescence (micro-XRF) and X-ray micro-computerized tomography (micro-CT), Fourier Transformed Infrared micro-spectroscopy (micro-FTIR) and Matrix-Assisted Laser Desorption/Ionisation-Time of Flight Mass Spectrometry (MALDI-TOF-MS) [22-34] to fully characterize the gilded composites at different scales [26], describing main features of the analyzed samples from macroscopic to micro and molecular levels. Micro-CT [23-25] is a relatively recent technique useful for non-destructively studying the three-dimensional internal structure and texture of a polychrome sample, ranging from microscopic to macroscopic spatial scales. This can be performed after 3D reconstruction of its internal architecture enabling 2D and 3D interactive static and dynamic visualization by means of pictures and movies, respectively. An improved and faster approach to the identification of proteinaceous constituents in these samples can be done by complementing the cross-section observation under optical microscope upon the fluorescent staining [25-26] with the binder identification through MALDI-TOF-MS [30-32] and micro-FTIR [20, 22, 33-34]. 
A comparative interdisciplinary study of gilding techniques and materials in two Portuguese Baroque "talha dourada" complexes

I.C.A. Sandu, E. Murta, E. R. Neves, M.F.C. Pereira, A. V. Sandu, S. Kuckova, A. Maurício

\section{Sampling}

To study the materiality of both gilded complexes, 7 samples from the "talha" in Lisbon (abbreviated MNAA) and 10 samples from the one in Santarém district (abbreviated VF) were taken in order to obtain cross-sections and to provide materials for spectroscopic, micro-analysis and tomographic reconstruction. The description of the micro-fragments and the analyses performed on each of them are given in the Table 1.

Table 1. Description of the samples and performed analyses

\begin{tabular}{|c|c|c|c|}
\hline & $\begin{array}{l}\text { Sample } \\
\text { ID }\end{array}$ & Sampling area & Analyses \\
\hline \multirow{7}{*}{ 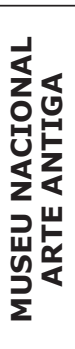 } & MNAA1 & Nave, lateral altar decoration & $\begin{array}{l}\text { MO, XRF, SEM-EDX, fluorescent stain, MALDI- } \\
\text {-TOF MS }\end{array}$ \\
\hline & MNAA2 & Nave, lateral altar decoration & MO, SEM-EDX, micro-CT, fluorescent stain \\
\hline & MNAA3 & Nave, lateral altar - left side decoration & $\mathrm{MO}$, micro-CT \\
\hline & MNAA4 & Lateral Chapel of S. Teresa, altar decoration & MO, XRF, SEM-EDX, MALDI-TOF MS \\
\hline & MNAA 5 & Lateral Chapel of S. Teresa, altar decoration & $\begin{array}{l}\text { MO, XRF, SEM-EDX, fluorescent stain, MALDI- } \\
\text {-TOF MS }\end{array}$ \\
\hline & MNAA6 & Lateral Chapel of S. Teresa & MO \\
\hline & MNAA7 & Nave, abgel - right side wall decoration & MO, SEM-EDX, micro-CT \\
\hline \multirow{10}{*}{ 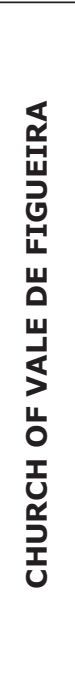 } & VF1 & Decoration from the door of the central altar, & MO, XRF, SEM-EDX, micro-FTIR \\
\hline & VF2 & $\begin{array}{l}\text { Upper part of the small right column - right } \\
\text { side of the decoration of the central altar }\end{array}$ & MO \\
\hline & VF3 & $\begin{array}{l}\text { Upper part of the base of the right column - } \\
\text { right side of the decoration of the central altar } \\
\text { (Tabernacle) }\end{array}$ & $\begin{array}{l}\text { MO, XRF, SEM-EDX, micro-FTIR, micro-CT, flu- } \\
\text { orescent stain, MALDI-TOF MS }\end{array}$ \\
\hline & VF4 & $\begin{array}{l}\text { Leaf of the chapitel of the right column - right } \\
\text { side of the decoration of the central altar }\end{array}$ & MO, XRF \\
\hline & VF5 & $\begin{array}{l}\text { Base of the right column - right side of the } \\
\text { decoration of the central altar }\end{array}$ & MO \\
\hline & VF6 & $\begin{array}{l}\text { Decoration of the lateral wall, left side from } \\
\text { the altar (three-dimensional leaf decoration) }\end{array}$ & MO, XRF, micro-FTIR \\
\hline & VF7 & $\begin{array}{l}\text { Decoration of the lateral wall, left side from } \\
\text { the altar (flat decoration) }\end{array}$ & $\begin{array}{l}\text { MO, XRF, SEM-EDX, microFTIR, micro-CT, stain } \\
\text { MALDI-TOF MS }\end{array}$ \\
\hline & VF8 & $\begin{array}{l}\text { Decorative column, "acantus" leaf from the } \\
\text { upper part }\end{array}$ & MO, XRF, SEM-EDX, micro-FTIR, stain \\
\hline & VF9 & $\begin{array}{l}\text { Decorative column, flat surface from the upper } \\
\text { part }\end{array}$ & MO, XRF, micro-CT, MALDI-TOF MS \\
\hline & VF10 & Decorative column, back side & XRF, MALDI-TOF \\
\hline
\end{tabular}

\section{Analytical protocol}

The historical data was complemented with the results obtained from the analytical interdisciplinary approach, in which microscopy (OM and SEM-EDX), spectroscopy (micro-XRF; micro-FTIR), fluorescent staining tests and X-ray tomography were applied for better understanding the structure, composition and conservation state of the gilded polychrome composites. Together with the microscopic and spectroscopic analyses, the micro-CT tool provided compositional information and imaging of the structural features of polychrome layers within the samples for the assessment of the manufacturing techniques, materials and of the surface conservation state. The main advantage of this non-destructive imaging 
A comparative interdisciplinary study of gilding techniques and materials in two Portuguese Baroque "talha dourada" complexes

I.C.A. Sandu, E. Murta, E. R. Neves, M.F.C. Pereira, A. V. Sandu, S. Kuckova, A. Maurício

technique is the fact that it allows visualizing the entire volume (inside and at the surface) of a sample throughout, a great number (hundreds or thousands) of sections/slices. In particular, this visual information can be obtained slicing all the sample volume through three conveniently chosen orthogonal principal cut types: transaxial, coronal and sagittal corresponding respectively to $Z Z^{\prime}, X X^{\prime}$ and $Y Y^{\prime}$ observation directions.

The identification of organic constituents in these samples (binders, varnishes or other organic materials) was done by complementing the cross-section observation under optical microscope (without stain, before and after fluorescent stain) with MALDI-TOF-MS and micro-FTIR identification.

\subsection{Optical microscopy and staining procedure on cross-sections}

The cross-sections, obtained from micro-fragments of the gilded samples, were embedded in Polyester resin Mecaprex SS (Leica) and properly polished after the necessary curing time. Their observation was done using an Axioplan Zeiss 2 imaging binocular microscope (50x - 500x magnification), with both Visible and fluorescent light, and a Nikon DXM1200F digital camera. The filter blocks used for observing the fluorescence were f8 (G 365, FT 395 and LP 420) and f6 (BP 450-490, FT 510 and LP 515). Visible light observations (illumination position for dark field observation, abbreviated as $\mathrm{f} 2$ ) were performed in reflection geometry. A non-covalent stain (Sypro Ruby, commercialized by Molecular Probes, USA) was used for fluorescence microscopic mapping of proteinaceous materials in cross-sections [28-29]. This fluorescent stain is used in the proteomics field and its advantages (nanogram sensitivity, high selectivity, low detection limit, a straightforward staining procedure and its availability as a ready-to-use solution) make it suitable for routine examination of paint samples [2829]. A drop of the stain solution is applied directly on the surface of the cross-section and left for few seconds up to 1-2 minutes. The excess of solution is removed with absorbent paper and afterwards the sample is ready for observation under microscope, using a proper filter set (f6) with emission in green light (the positive staining has a bright orange color).

\subsection{X-ray fluorescence analysis}

Micro-XRF was done using a portable spectrometer (ArtTAX Pro), in the following experimental conditions: voltage $40 \mathrm{kV}$; current $600 \mathrm{~mA}$; accumulation time $120 \mathrm{~s}$; spatial resolution 70 $\mathrm{mm}$. The measurement was performed both on micro-fragments and cross-sections.

\subsection{Scanning Electron Microscopy - Energy Dispersive X-ray Spectrometry}

A SEM - VEGA II LSH Scanning Electron Microscope (TESCAN - Czech Republic), coupled with an EDX - QUANTAX QX2 (ROENTEC - Germany) spectrometer was used. Quantax QX2 uses a detector of third generation Xflash, that does not need cooling with nitrogen and is 10 times faster than a traditional detector based on $\mathrm{Si}(\mathrm{Li})$. The EDX spectra have been 
A comparative interdisciplinary study of gilding techniques and materials in two Portuguese Baroque "talha dourada" complexes

I.C.A. Sandu, E. Murta, E. R. Neves, M.F.C. Pereira, A. V. Sandu, S. Kuckova, A. Maurício

acquired in the following conditions: $20 \mathrm{KV}$ voltage; $1 \times 10-3 \mathrm{~Pa}$; 5000nA; working distance 11-20 mm (16.6 mm for EDX), scanning speed: 200ns; magnification: 78x and 1000x. The cross-sections were covered with a fine layer of graphite using a specific "sputter coater".

\subsection{Micro-computerized tomography}

The micro-tomographical study was performed on 6 samples using a compact desktop high resolution Skyscan 1172 micro-tomograph. The analytical set-up consists of the combination of an X-ray shadow microscopic system and a computer with tomographic reconstruction and analysis software. The Skyscan 1172 contains an X-ray micro-focus tube with high-voltage power supply, a specimen stage with precision manipulator, a 2-D X-ray CCD-camera connected to the frame-grabber and a Dual Pentium computer with colour monitor.

In order to obtain high-resolution radiographs, milimetric samples are preferred. X-ray source and detector are fixed while the sample rotates around a stable vertical axis ( $\left.Z Z^{\prime}\right)$. Samples were scanned at a voltage of $100 \mathrm{kV}$ with current intensity at $100 \mathrm{~mA}$. A random movement of five with a five frame averaging was chosen to minimise noise. The basic physical parameter quantified in each pixel of a CT-shadow image (radiograph) is the linear attenuation coefficient. Beer's law relates the intensity (I) of X-ray photons passing through the object with thickness $h$, with the incoming intensity (Io) and the attenuation coefficient (a) of the object.

The X-ray micro-tomograph settings and operation procedure were optimised to produce the best phase contrast images by reducing artefacts like beam hardening, ring, star and line artefacts as much as possible.

\subsection{Fourier Transformed Infrared Micro-spectroscopy}

A Nicolet Nexus spectrophotometer interfaced with a Continuum microscope with a MCT-A detector cooled by liquid nitrogen was used. The spatial resolution is $30 \mathrm{~mm}$, the spectra being obtained with a resolution of $4 \mathrm{~cm}^{-1}$ and 128 scans, in transmission mode, in an interval between 4000 and $650 \mathrm{~cm}^{-1}$, using a Thermo diamond anvil compression cell.

\subsection{Matrix-Assisted Laser Desorption/Ionisation-Time of Flight Mass Spectrometry}

Reagents - Trypsin (TPCK) from Promega Corporation, trifluoroacetic acid and 2,5-dihydroxybenzoic acid (DHB) both from Sigma, acetonitrile (p.a.) and ammonium hydrogen carbonate from Lachema Brno were used. The commercially available reverse phase ZipTip comes from Millipore Corporation, Bedford, MA, USA.

Specific cleavage with trypsin - Digestion of approximately $20 \mathrm{mg}$ of each sample was carried out in $50 \mu \mathrm{L}$ of solution containing $1 \mu \mathrm{g} / \mu \mathrm{L}$ of sequencing grade trypsin (Promega) in 50 
A comparative interdisciplinary study of gilding techniques and materials in two Portuguese Baroque "talha dourada" complexes

I.C.A. Sandu, E. Murta, E. R. Neves, M.F.C. Pereira, A. V. Sandu, S. Kuckova, A. Maurício

$\mathrm{mM} \mathrm{NH}_{4} \mathrm{HCO}_{3}$ at room temperature for 2 hours. The solution containing released peptides was desalted using ZipTips packed with reversed phase (C18) resin.

All mass spectra were acquired using a Bruker-DaltonicsBiflex IV MALDI-TOF mass spectrometer equipped with standard nitrogen laser $(337 \mathrm{~nm}$ ) in reflector mode. A $2 \mu$ l aliquot of the peptide mixture was mixed with $4 \mu \mathrm{l}$ of DHB solution ( $16 \mathrm{mg}$ DHB in $1 \mathrm{ml}$ of a mixture of acetonitrile and $0.1 \%$ trifluoroacetic acid $(1: 2 \mathrm{v} / \mathrm{v})$. A $2-\mu \mathrm{l}$ aliquot of the resulting solution was spotted on a stainless steel MALDI target plate and let to evaporate before analysis. At least 200 laser shots were collected for each spectrum and the data were analysed using the software package XMASS (Bruker) and the freely available open source tool mMass [30-32].

\section{Results and discussion}

In the Table 2, a summary of the results from the whole analytical protocol is presented.

Table 2. Results from the analyzed samples

\begin{tabular}{|c|c|c|c|c|c|c|}
\hline \multicolumn{2}{|c|}{$\begin{array}{l}\text { Sample } \\
\text { ID }\end{array}$} & $\begin{array}{l}\text { Decorative part } \\
\text { or element }\end{array}$ & \multirow{2}{*}{$\begin{array}{l}\text { Stratigraphical } \\
\text { description } \\
(\mathrm{MO}, \mathrm{Vis}-\mathrm{UV} \text { and } \\
\text { micro-CT) } \\
\text { GR } \\
\end{array}$} & \multirow[t]{2}{*}{$\begin{array}{l}\text { Elements for each } \\
\text { layer } \\
(X R F, S E M)\end{array}$} & \multirow[t]{2}{*}{\begin{tabular}{|l} 
Inorganic \\
component \\
(micro-FTIR)
\end{tabular}} & \multirow[t]{2}{*}{$\begin{array}{l}\text { Organic component } \\
\text { (micro-FTIR, MALDI- } \\
\text {-TOF-MS, fluorescent } \\
\text { stain) } \\
\text { Animal (rabbit) glue }\end{array}$} \\
\hline \multirow{11}{*}{$\frac{5}{z}$} & \multirow{4}{*}{$1-3$} & \multirow[t]{4}{*}{ Nave } & & & & \\
\hline & & & $\mathrm{OL}$ & $\mathrm{Si}, \mathrm{Al}, \mathrm{Fe}, \mathrm{Mg}, \mathrm{K}, \mathrm{Ti}$ & \multirow[t]{3}{*}{-} & \\
\hline & & & Gold leaf & $\mathrm{Au}(\mathrm{Ag}-\mathrm{Cu})$ & & \\
\hline & & & Particulate deposit & & & \\
\hline & \multirow{4}{*}{ 4-6 } & \multirow{4}{*}{$\begin{array}{l}\text { Lateral Chapel of } \\
\text { S. Teresa }\end{array}$} & GR & $\mathrm{Ca}, \mathrm{S}, \mathrm{O}, \mathrm{Sr}$ & \multirow{4}{*}{-} & \multirow[t]{2}{*}{ Animal (rabbit) glue } \\
\hline & & & $\mathrm{OL}$ & $\mathrm{Si}, \mathrm{Al}, \mathrm{Fe}, \mathrm{K}, \mathrm{Mn}, \mathrm{Ti}$ & & \\
\hline & & & Gold leaf & $\mathrm{Au}(\mathrm{Ag}-\mathrm{Cu})$ & & \\
\hline & & & $\begin{array}{l}\text { Wax or other } \\
\text { varnish? }\end{array}$ & & & \\
\hline & \multirow{3}{*}{7} & \multirow{3}{*}{$\begin{array}{l}\text { Nave, entrance } \\
\text { to the Chapel of } \\
\text { the Lord of the } \\
\text { Speech }\end{array}$} & $\mathrm{GR}$ & $\mathrm{Ca}, \mathrm{S}, \mathrm{O}$ & \multirow{3}{*}{-} & \multirow{3}{*}{ - } \\
\hline & & & $\mathrm{OL}$ & $\mathrm{Si}, \mathrm{Al}, \mathrm{Fe}, \mathrm{Mg}$ & & \\
\hline & & & Gold leaf & $\mathrm{Au}(\mathrm{Ag}-\mathrm{Cu})$ & & \\
\hline \multirow{11}{*}{$\stackrel{4}{>}$} & \multirow{4}{*}{$1-5$} & \multirow[t]{4}{*}{ Main altarpiece } & GR & $\mathrm{Ca}, \mathrm{S}, \mathrm{O}, \mathrm{Sr}$ & \multirow{4}{*}{$\begin{array}{l}\text { Gypsum } \\
\text { Clays }\end{array}$} & \multirow[t]{3}{*}{ Animal (rabbit) glue } \\
\hline & & & $\mathrm{OL}$ & $\mathrm{Si}, \mathrm{Al}, \mathrm{Fe}, \mathrm{Mg}, \mathrm{K}, \mathrm{Ti}$ & & \\
\hline & & & Gold leaf layers & $\mathrm{Au}(\mathrm{Ag}-\mathrm{Cu})$ & & \\
\hline & & & $\begin{array}{l}\text { Wax surface layer } \\
\text { (VF3) }\end{array}$ & & & Wax (VF3) \\
\hline & \multirow{4}{*}{$6-7$} & \multirow{4}{*}{$\begin{array}{l}\text { Lateral wall, } \\
\text { decoration }\end{array}$} & GR & $\mathrm{Ca}, \mathrm{S}, \mathrm{O}, \mathrm{Sr}$ & \multirow{4}{*}{$\begin{array}{l}\text { Gypsum } \\
\text { Clays }\end{array}$} & \multirow[t]{3}{*}{ Animal (rabbit) glue } \\
\hline & & & Very thin OL & $\mathrm{Si}, \mathrm{Al}, \mathrm{Fe}, \mathrm{Mg}, \mathrm{Ti}$ & & \\
\hline & & & Gold leaf & $\mathrm{Au}(\mathrm{Ag}-\mathrm{Cu})$ & & \\
\hline & & & $\begin{array}{l}\text { Thick protective } \\
\text { layer, not fluores- } \\
\text { cent under UV light } \\
\text { (VF7) }\end{array}$ & & & $\begin{array}{l}\text { Waxy material (sur- } \\
\text { face layer of VF7) }\end{array}$ \\
\hline & \multirow{3}{*}{ 8-10 } & \multirow{3}{*}{$\begin{array}{l}\text { Decorative } \\
\text { column, single } \\
\text { element }\end{array}$} & GR & $\mathrm{Ca}, \mathrm{S}, \mathrm{O}, \mathrm{Sr}$ & \multirow{3}{*}{$\begin{array}{l}\text { Gypsum } \\
\text { Clays }\end{array}$} & \multirow[t]{3}{*}{ Animal (rabbit) glue } \\
\hline & & & Two Red OL & $\mathrm{Si}, \mathrm{Al}, \mathrm{Fe}, \mathrm{Mg} \mathrm{K}, \mathrm{Ti}$ & & \\
\hline & & & Gold leaf (lamina) & $\mathrm{Au}(\mathrm{Ag}-\mathrm{Cu})$ & & \\
\hline \multicolumn{3}{|c|}{ Abbreviations } & \multicolumn{4}{|c|}{$\begin{array}{l}\text { MNAA - National Museum of Ancient Art; VF - Vale de Figueira; GR - Thick } \\
\text { white Ground; OL - Ochre Layer (bole?); Clays - Clay minerals }\end{array}$} \\
\hline
\end{tabular}


A comparative interdisciplinary study of gilding techniques and materials in two Portuguese Baroque "talha dourada" complexes

I.C.A. Sandu, E. Murta, E. R. Neves, M.F.C. Pereira, A. V. Sandu, S. Kuckova, A. Maurício

\subsection{Stratigraphical structure and characteristics of inorganic phases (OM, SEM- -EDX, micro-CT)}

Figure 3 gives the stratigraphical structure corresponding to various samples, at different magnifications. The MNAA's "talha" presents a uniform stratigraphic structure in all the 7 samples: from the bottom thick layer of ground (coherent and dense, without particular inclusions or infiltrations) to the ochre bole layer and the upper layer of gilding (Figure 3) made of an alloy-based lamina $(\mathrm{Au} / \mathrm{Ag} / \mathrm{Cu})$. Residues of a wax-resin mixture and of atmosphere particulate are also present on the surface of the precious leaf. This data is consistent with the results presented elsewhere [12] on three samples from different areas (and belonging to different epochs) of the gilded decoration in this church. In this case the cross-section observation was used to assess the effectiveness of the wax-resin method [12]. In some cases the optical observation illustrates de impregnation of the whole sample (MNNA3 and 4, Figure 3) with the mixture used for consolidation, suggesting that in lacunar areas from the gilded decoration the mixture penetrated into the gilded composite, while in other fragments (MNAA1 and 2, Figure 3) remained on the surface of the leaf. Therefore the consolidation product assured protection and stability to the whole gilded composite.

For four samples taken from the VF complex, similar structure of layers to the "talha" from MNAA can be described: white thick ground with inclusions of variable size; layer of red-yellow ochre (bole?), gold leaf and waxy varnish (translucent in visible light).

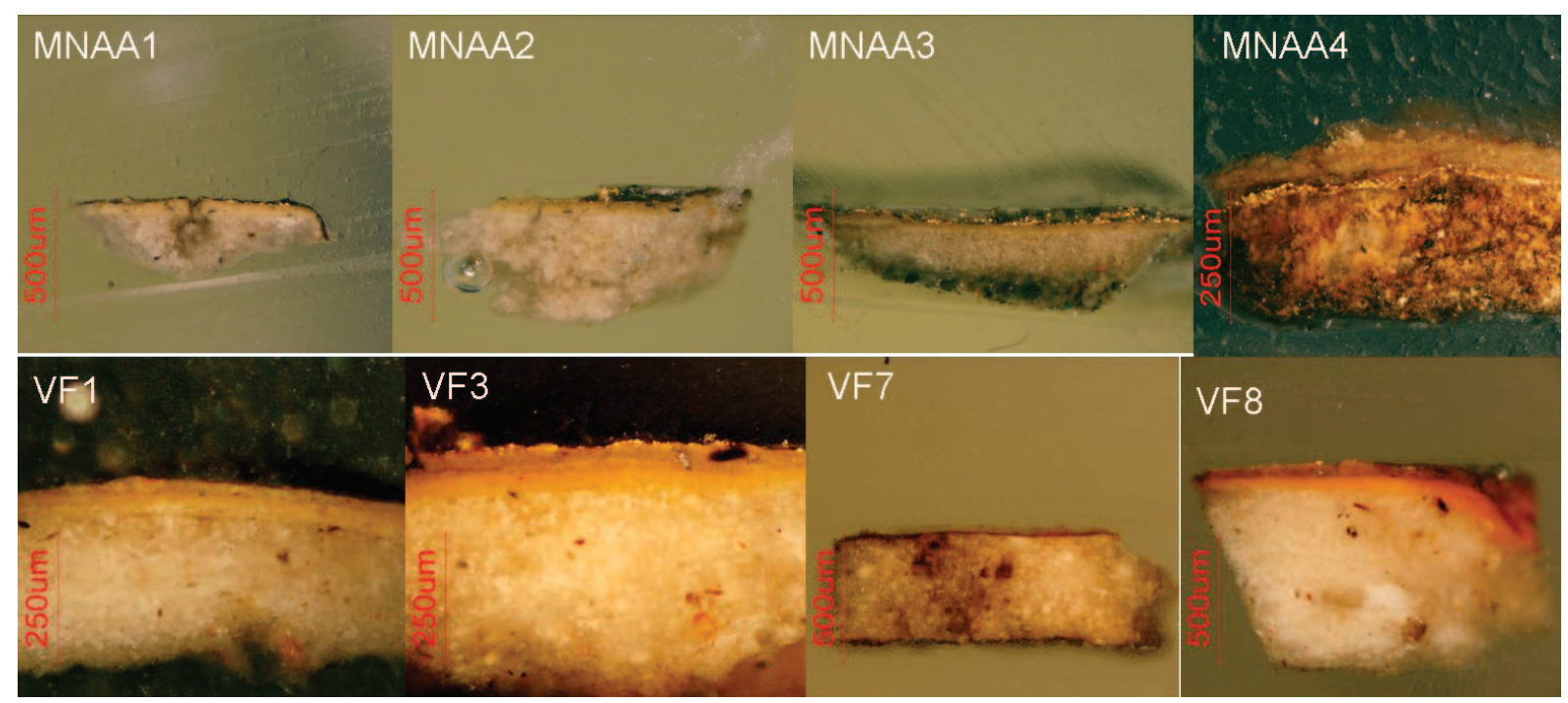

Figure 3. Selection of samples from MNAA's and VF's "talhas", observed and photographed under optical microscope, in the form of cross-sections

Figure 4 shows some examples of micro-CT slice images taken from the interior of 2 samples, VF7 and MNAA3. These images illustrate the three-dimensional structure of each sample in 3 directions $(x, y, z)$ and the phase contrast inside the sample's architecture. The metal leaf is clearly distinguished from the non-metallic components (MNAA3) of the stratigraphical 
A comparative interdisciplinary study of gilding techniques and materials in two Portuguese Baroque "talha dourada" complexes

I.C.A. Sandu, E. Murta, E. R. Neves, M.F.C. Pereira, A. V. Sandu, S. Kuckova, A. Maurício

structure (different colours were used to better show this distinction). Holes or pores, structural discontinuity and irregular patterns, big inclusions and fractures inside the samples can be visualized with this technique and correlated with the compositional features.

In Figure 4, each color/grey scale image represents a section of the radiographic tomographic reconstruction of the inner structure of the sample: $\mathrm{T}$ - transaxial; $\mathrm{S}$ - sagittal; C - coronal. The red line in the RST image indicates the position of the transaxial section (T section). The resolution used for these images was: $4.27 \mu \mathrm{m} /$ pixel for MNAA3 and $2.85 \mu \mathrm{m} /$ pixel for VF7.

The sample from VF (VF7) displays a ground with heterogeneous porosity (big pores and also small, diffused ones) in which an interface is present between two different ground layers: the upper one, with high porosity, and the lower, thinner one, more compact.

In the case of the sample from MNAA (MNAA3), the various sections obtained through micro-CT scanning show a ground that has a relatively homogenous granulometry and sporadic porosity (big pores or holes can be detected within the structure) and with discontinuities due to fissures or small lacunae in the surface layers (indicating also a poor conservation state with a loss of cohesion between layers and also disaggregation of the particles inside the ground). This sample has an irregular shape and the $T$ and $C$ sections also show a separation surface within the ground layers. Small, bright inclusions (particles that generate very high beam attenuation) were also detected and were attributed to the presence of impurities. Those impurities could include iron oxides or other compounds having in their composition heavier chemical elements.
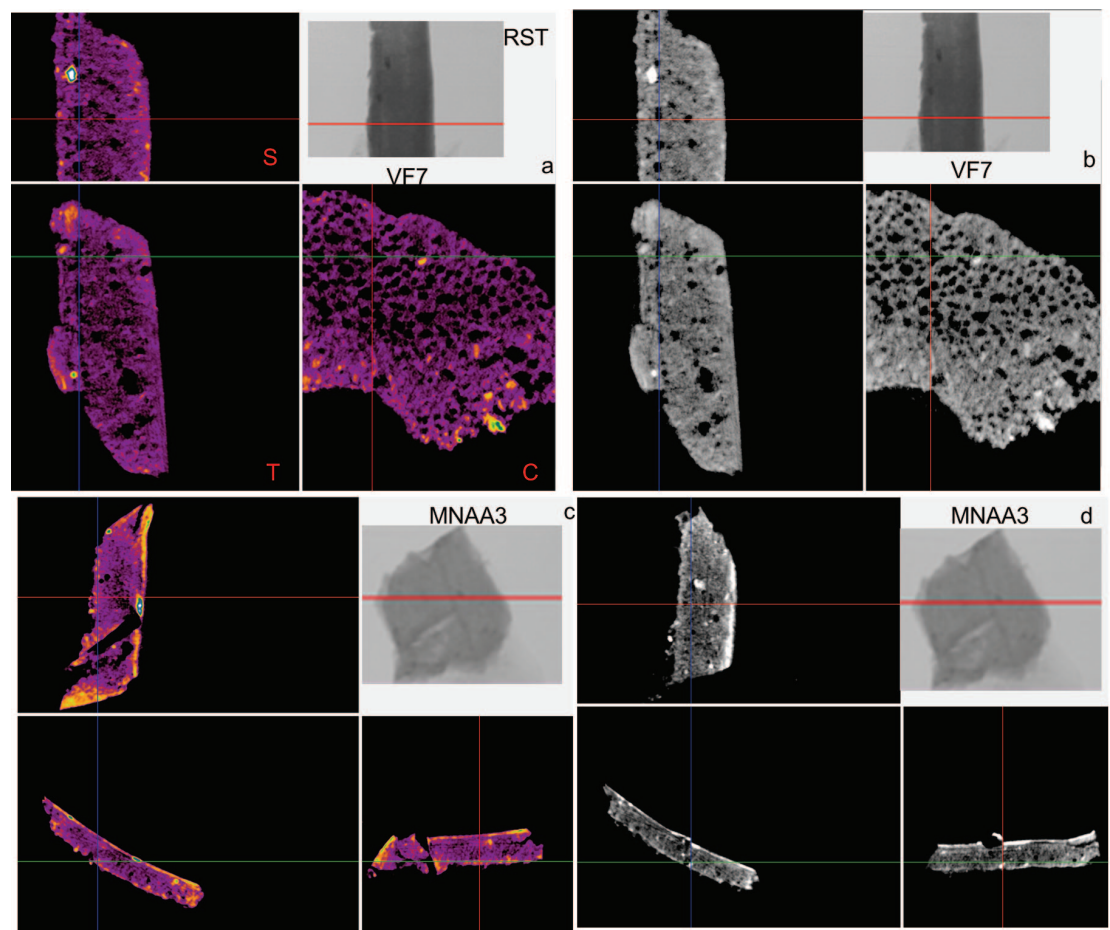

Figure 4. Micro-CT reconstructions of 2 samples: a) VF7 color images; b) VF7 grey scale images; c) MNAA3 color images, d) MNAA3 grey scale images. 
A comparative interdisciplinary study of gilding techniques and materials in two Portuguese Baroque "talha dourada" complexes

I.C.A. Sandu, E. Murta, E. R. Neves, M.F.C. Pereira, A. V. Sandu, S. Kuckova, A. Maurício

An interesting contribution given by microCT in this case is the possibility of distinguishing between the coarse layers of gesso grosso and finer gesso matte, which presence characterize the water gilding technique [35-37]. This dynamic observation can be complemented with the SEM imaging that also allows differentiating the distribution and orientation of gypsum grains within different layers (Figure 5, samples MNAA4 and VF7-VF8). Not all the samples in this study allowed assessing the different morphology between the coarse gesso grosso and the fine gesso matte, but for some of them (as MNAA7) it was possible to cross-reference the results of the two imaging techniques, SEM and microCT, thus showing where the gesso grosso vs. gesso matte distinction is more obvious (Figure 5). MicroCT images for MNAA7 in Figure 5 have a resolution of $3.91 \mu \mathrm{m} /$ pixel.

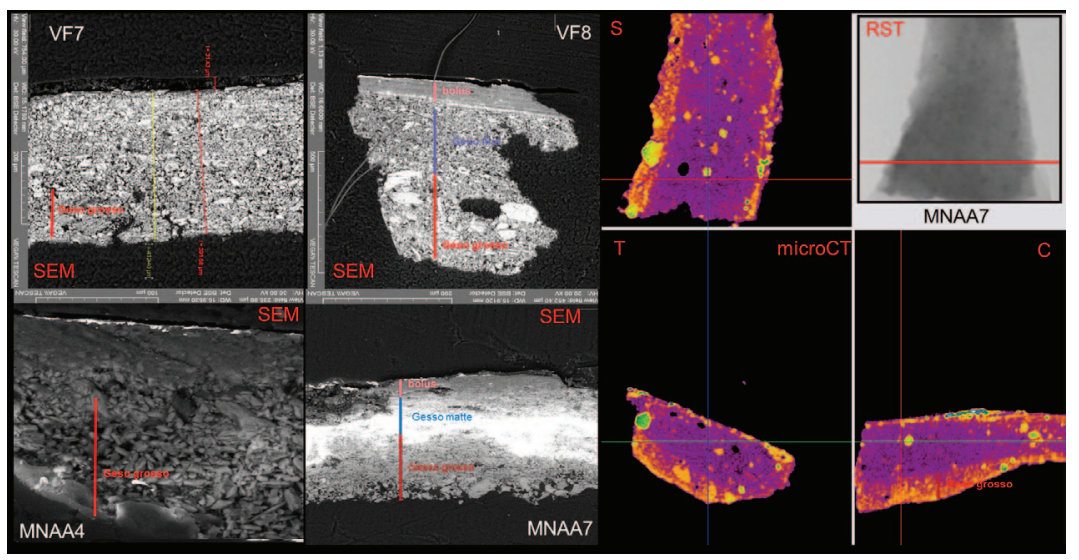

Figure 5. SEM and micro-CT imaging of samples showing the difference between gesso grosso and gesso matte layers

For the sample MNAA4 (Figure 5) the SEM backscattered electrons image shows clearly different morphological and size dimension characteristics between the ground layer and the bole, that is much finer than the gesso (presenting long shaped crystals). The same distinction in shape and size between the grains of the ground and the upper ochre layer is also visible for VF samples (VF8-VF7 in Figure 5 and VF3 in Figure 6).

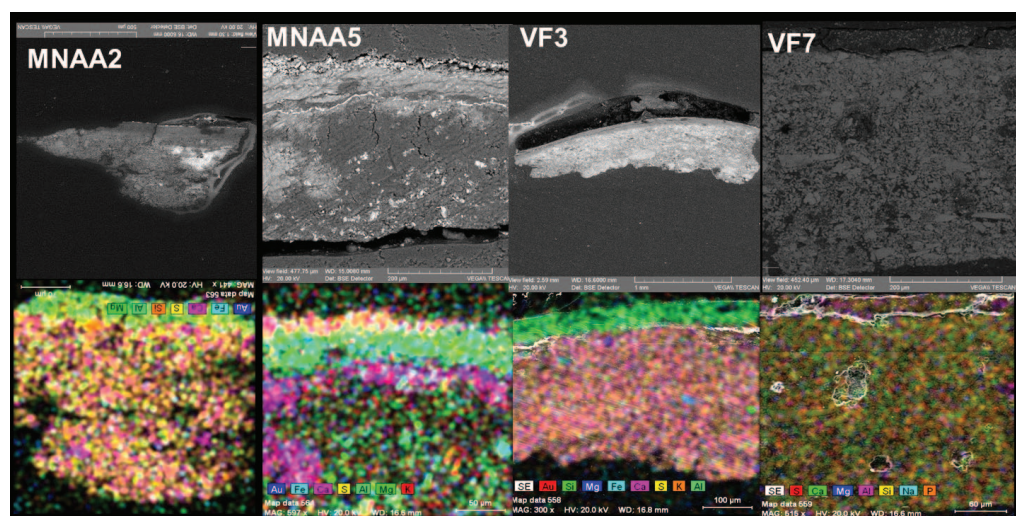

Figure 6. SEM-EDX imaging and mapping for 2 MNAA samples and 2 VF samples. 
A comparative interdisciplinary study of gilding techniques and materials in two Portuguese Baroque "talha dourada" complexes

I.C.A. Sandu, E. Murta, E. R. Neves, M.F.C. Pereira, A. V. Sandu, S. Kuckova, A. Maurício

\subsection{Compositional features (micro-XRF, SEM-EDX, micro-FTIR, MALDI-TOF-MS, fluorescent stain)}

The elemental mapping performed by micro-XRF and SEM-EDX allowed distinguishing between the elements present in the ground layers and bole (Table 2) and also those characterizing the composition of the gold leaf (Table 3). The EDX analyses allowed to identify the presence of a gold-based alloy in all the samples (Table 3).

Table 3. Compositional identification of the gold leaf in 2 samples by SEM-EDX (weight and atomic \% for each element in the metallic leaf)

\begin{tabular}{|llllll|}
\hline $\begin{array}{l}\text { Sample } \\
\text { ID }\end{array}$ & Element & Series & [norm. wt.-\%] & [norm. at.-\%] & Error in \% \\
\hline & $\mathrm{Au}$ & M-series & $\mathbf{9 5 , 0 0 6}$ & 89,446 & 4,124 \\
VF8 & $\mathrm{Ag}$ & L-series & 3,352 & 5,762 & 0,173 \\
& $\mathrm{Cu}$ & K-series & 1,642 & 4,792 & 0,108 \\
\hline \multirow{2}{*}{ MNAA5 } & $\mathrm{Au}$ & M-series & $\mathbf{8 6 , 6 4 4}$ & 74,761 & 4,259 \\
& $\mathrm{Ag}$ & L-series & 9,537 & 15,027 & 0,620 \\
& $\mathrm{Cu}$ & K-series & 3,819 & 10,213 & 0,428 \\
\hline
\end{tabular}

$\mathrm{Au} / \mathrm{Ag} / \mathrm{Cu}$ leaf was detected in both cases, with a different atomic ratio between elements (Au:Ag:Cu). For the samples from MNAA (Table 3) the alloy $\mathrm{Au}: \mathrm{Ag}: \mathrm{Cu}=7.5: 1.5: 1$ has 86\% (w\%) of Au, corresponding to 21 carat gold. Samples from VF have a ratio of 19:1.2:1 (Table 3 ) and a massic composition of $95 \% \mathrm{Au}$, corresponding to an alloy of 23 carat gold. The use of highly gold-content alloys ( $87 \% \mathrm{Au}$ ) and of alloys made of $\mathrm{Au} / \mathrm{Ag} / \mathrm{Cu}$ was already reported from an extensive and comparative SEM-EDX research performed on several Portuguese polychrome reliquaries from Alcobaça, Açores, Coimbra, Aveiro, Tibães (16 ${ }^{\text {th }}$ century) [3, $26]$ and in other studies on retables from Coimbra (Cathedral's main altarpiece, dated from 1502 to 1685) and Porto, dated from 17th-18th centuries [5-8] where 22-23 carat gold is reported (applied as water or mordant based techniques, the stratigraphy being characterized by the presence of ground, red bole layer and gold leaf). Our results confirm the extensive use of such alloys during $17^{\text {th }}$ and $18^{\text {th }}$ centuries up to $19^{\text {th }}$ century in Portugal.

Although the analytical procedures can indicate the quantitative composition and the quality of the alloy, measuring the thickness of the gold leaf when laid in "talha dourada" structure, is extremely difficult. For MNAA samples the thickness of the leaf is approximately $5 \mathrm{~mm}$ and $10 \mathrm{~mm}$ for VF samples. Can this indicate that the gold beaters were more skilled and able laminating the thin gold leaf in a central town like Lisbon than in smaller communities like Santarém? It is known that the gold leaf quality and thickness depended not only of the astonishing malleability of the metal, but also of the subtle qualities and compressibility characteristics of the surface of the sheet material between which gold was confined during the beating. Although Natália Marinho Alves and other authors [4, 35] speaks of good quality of the gilding work, giving information about artists, materials and gilding technical 
A comparative interdisciplinary study of gilding techniques and materials in two Portuguese Baroque "talha dourada" complexes

I.C.A. Sandu, E. Murta, E. R. Neves, M.F.C. Pereira, A. V. Sandu, S. Kuckova, A. Maurício

procedures, there are a lot of technical data to be confirmed by extended studies (hopefully to be obtained within the Gilt-Teller project)[38].

The presence of elements such as $\mathrm{Ca}(\mathrm{Sr}), \mathrm{O}, \mathrm{S}$, is attributed to the ground made of calcium sulphates (e.g. gypsum). The micro-FTIR analysis of VF7 (Figure 7b) confirmed the presence of gypsum ( $3408 \mathrm{~cm}^{-1}-\mathrm{H}_{2} \mathrm{O} ; 1621 \mathrm{~cm}^{-1}-\mathrm{H}-\mathrm{O}-\mathrm{H} ; 1117.68$ and $672 \mathrm{~cm}^{-1}-\mathrm{SO}_{4}^{2-}$ ) and probably clay minerals from the ochre upper layer (peaks detected in the interval $3700-3600 \mathrm{~cm}^{-1}$ attributed to the water; $970-1050$ and $915 \mathrm{~cm}^{-1}$ attributed to the Kaolinite-Illite group of phyllosilicates - Figure 7b)[34].

Kaolinite was detected together with gypsum in the composition of bole layers in the three samples coming from gilded decoration in the church of MNAA and analyzed in 2009 [12]. In our study all the bole layers analyzed display a high content of $\mathrm{Al}$ and $\mathrm{Si}$, corresponding to silicate minerals. Other elements identified by XRF and SEM-EDX (such as Fe, Mg, K, Ti) are typical of the bole layers, attributed to the clay minerals and ( $\mathrm{Fe}, \mathrm{Ti}, \mathrm{Mn}$ )-oxides.

Figures 8 and 9 illustrate the results of the microscopic mapping with the fluorescent stain on cross-sections and comparison with auto-fluorescence (images taken under UV light). The Sypro mapping (Figure 9) shows a diffused distribution of proteinaceous material in the ground and bole layers but in case of samples from MNAA (especially MNAA5) the stain's colour is altered because of the wax-resin impregnation. The varnish coating in the VF7 sample is not fluorescent under UV light and has similar appearance as the sample VF3 (Figure 7), in which the micro-FTIR identified the wax (2917.71 and $2849.56 \mathrm{~cm}^{-1}-\mathrm{CH}$ str; $1736.46 \mathrm{~cm}^{-1}-\mathrm{C}=\mathrm{O}$ str; $1463.26 \mathrm{~cm}^{-1}-\mathrm{CH}$ def; $1172.19 \mathrm{~cm}^{-1}-\mathrm{C}-0 ; 720 \mathrm{~cm}^{-1}-\mathrm{C}-\mathrm{C}$ str $)$ as surface layer (Figure 7a). The FTIR spectrum of VF7 (Figure 7b) identified only few peaks that could be attributed to an organic material (2923.40 and $2851.22 \mathrm{~cm}^{-1}$ for $\mathrm{CH}_{2}$ stretching) [33-34], while the absorption band around $1540 \mathrm{~cm}^{-1}\left(1536.73 \mathrm{~cm}^{-1}\right.$ - VF7 spectrum) could indicate the presence of a proteinaceous binder in the ground layers, successively confirmed by the results of MALDI-TOF-MS (Figure 10). The MALDI-TOF mass spectrometric analysis identified the presence of animal collagen (rabbit glue) in samples MNAA1, 4 and 5; VF3, 7, 9 and 10 (Figure 10). The peaks specific for the collagen in animal glues are labelled in the mass spectra. The peaks uniquely belonging to rabbit glue are in the following $\mathrm{m} / \mathrm{z}$ values: $1261,1263,1442,1709$, and 1831. 
A comparative interdisciplinary study of gilding techniques and materials in two Portuguese Baroque "talha dourada" complexes

I.C.A. Sandu, E. Murta, E. R. Neves, M.F.C. Pereira, A. V. Sandu, S. Kuckova, A. Maurício
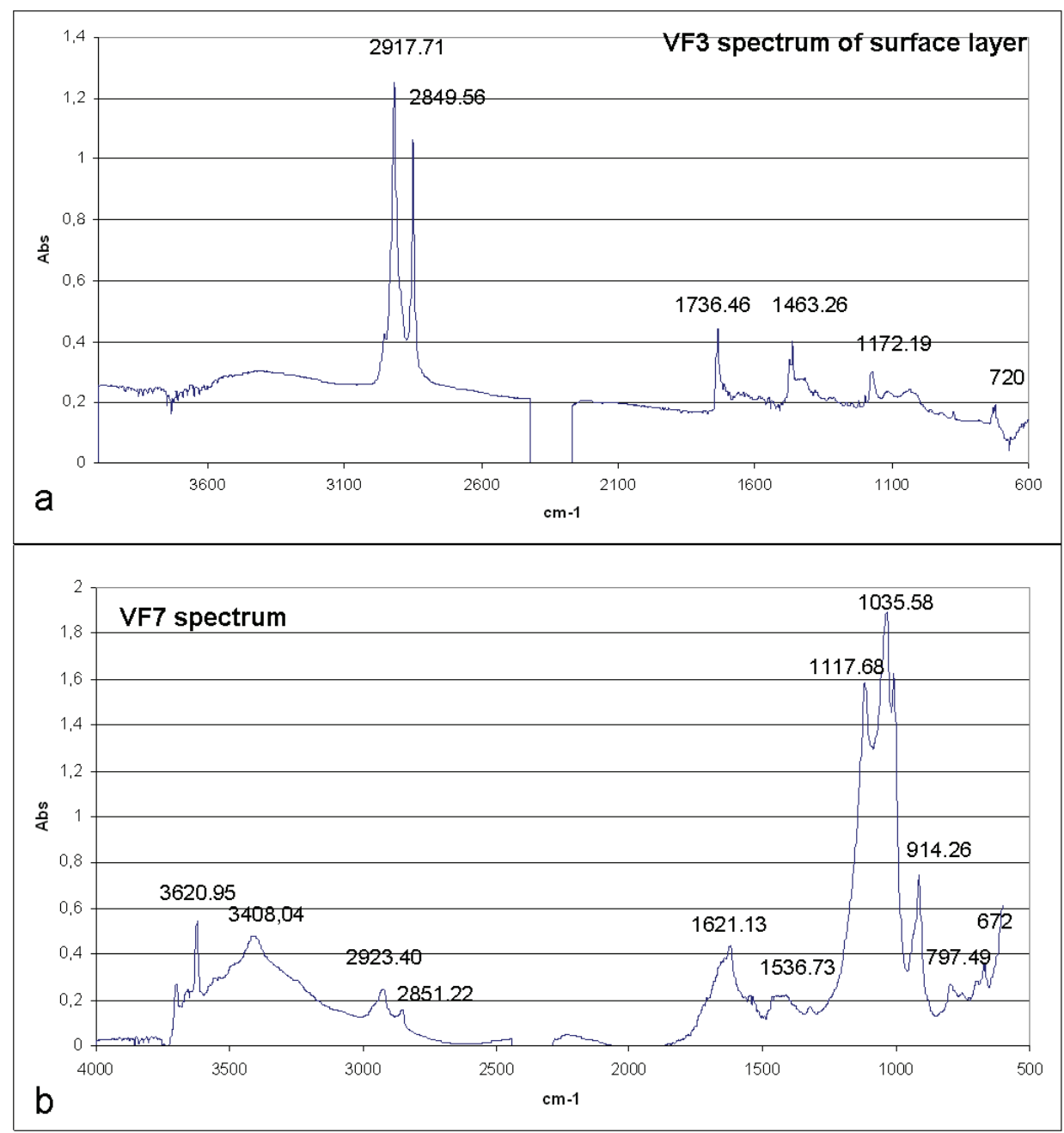

Figure 7. Micro-FTIR spectra of two samples from VF "talha":

a) protective surface layer from VF3; b) polychrome layers with residues of ground from VF7

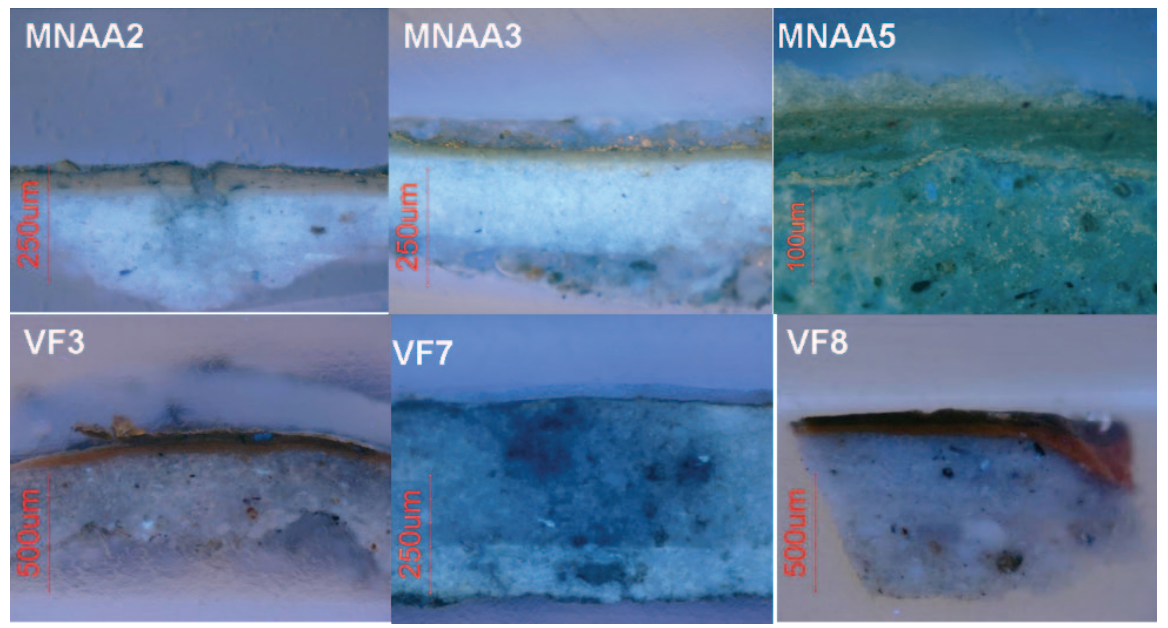

Figure 8. Fluorescent imaging (auto-fluorescence upon UV excitation) of samples of "talha dourada" ( 3 from MNAA and 3 from VF) 
A comparative interdisciplinary study of gilding techniques and materials in two Portuguese Baroque "talha dourada" complexes

I.C.A. Sandu, E. Murta, E. R. Neves, M.F.C. Pereira, A. V. Sandu, S. Kuckova, A. Maurício

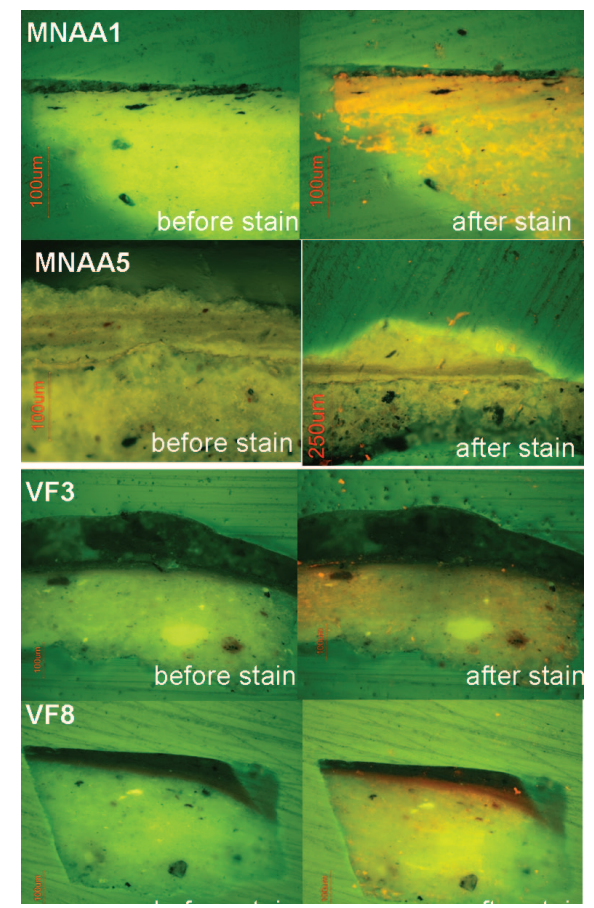

Figure 9. Fluorescent imaging (induced fluorescence upon Sypro staining) of samples of "talha dourada" ( 2 from MNAA and 2 from VF)
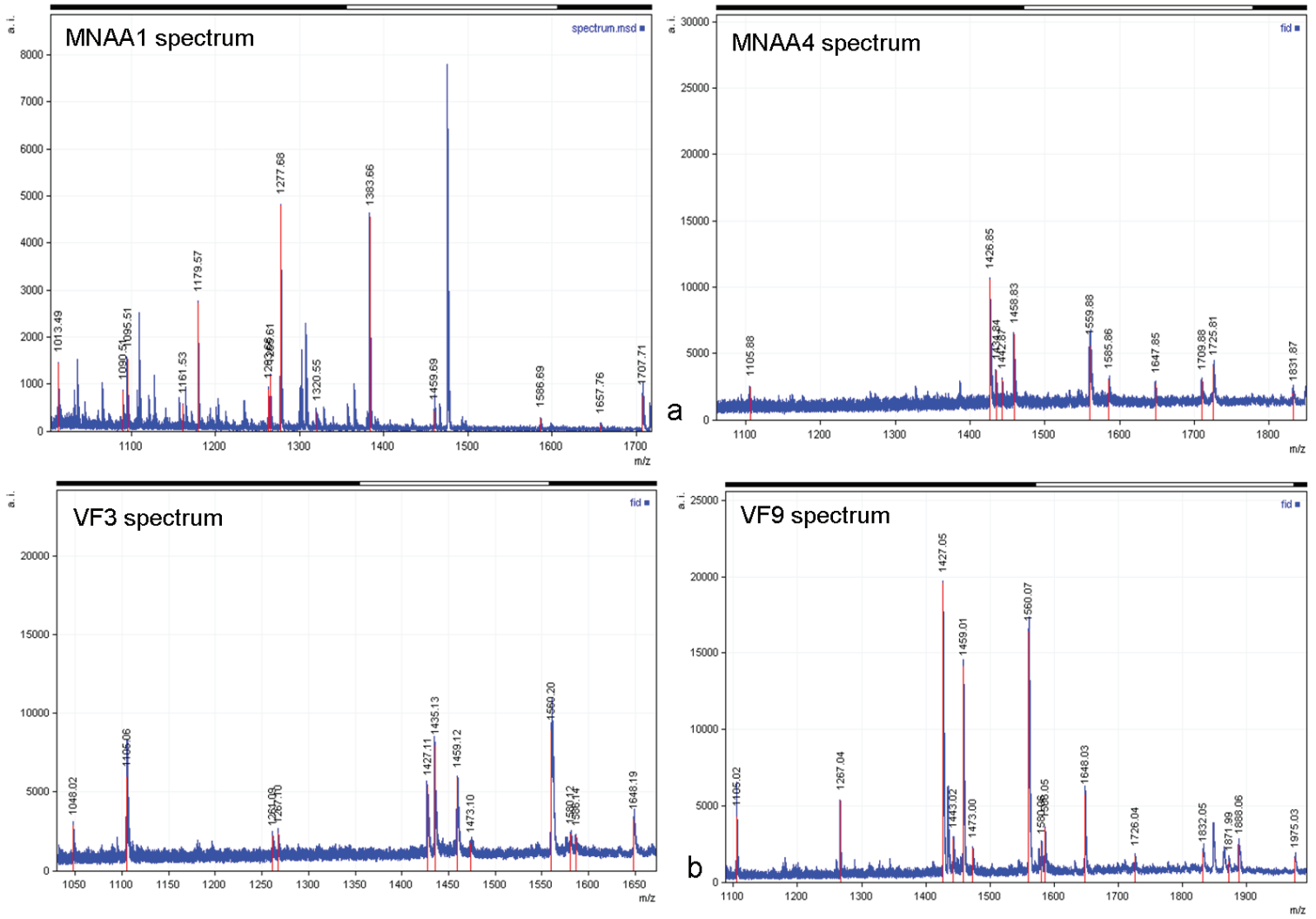

Figure 10. MALDI-TOF-MS spectra of: a) 2 samples from MNAA "talha"; b) 2 samples of VF "talha". The red peaks belong to the animal glue. 
A comparative interdisciplinary study of gilding techniques and materials in two Portuguese Baroque "talha dourada" complexes

I.C.A. Sandu, E. Murta, E. R. Neves, M.F.C. Pereira, A. V. Sandu, S. Kuckova, A. Maurício

\subsection{Conservation state and past interventions (OM, micro-CT)}

In MNAA5 sample (Figures 3 and 8 ) the image of the ground has a dark and greasy aspect. This can be due to impregnation treatment residues with a wax-resin mixture, performed in the past [12]. The light yellow coloration in the layer subjacent to the metal lamina was probably due to the impregnation with an oily/resinous material. This was confirmed by sample analysis done on areas of water gilding technique but contaminated with an oily material not original but belonging to surface layers [12].

The various reconstructed slices obtained through micro-CT scanning, contributed to characterizing the MNAA3 sample's conservation state. These images display discontinuities in the entire composite structure, from the surface layer to the ground, due to fissures or small lacunae open in the surface layers. The micro-CT technique enables visualizing the porosity distribution and homogeneity in the samples. This is useful to be correlated to the characteristics of the materials and the application procedure of these materials. Normally the white ground preparation was applied in several layers, initially the gesso grosso (coarser and with vermicular shaped crystals), thoroughly sanded between applications and afterwards the gesso matte, much finer and less porous. The separating interface between layers, with half cut crystals, can be detected with the OM and micro-CT observation.

Some of the samples from VF (VF3 and VF7, Figures 3 and 8) have a protective thick layer of wax (with a grey fluorescence pattern), identified by micro-FTIR spectroscopy (Figure 7). The presence of the wax as a varnish can be also associated with some not qualified intervention of cleaning and re-varnishing in case of the sample VF4 (from decorative columns of the altar). The liturgical use of wax candles would lead to localized presence of the wax but the analyzed samples did not allow differentiating between a generalized and a localized presence of this coating material.

\section{Conclusions}

The proposed integrated multi-technique protocol to investigate the two gilded complexes enabled to ascertain the similarities and differences in the structure, materials and techniques of both "talha dourada" samples. In this respect, it was found that the stratigraphical structure of the gilding layers is quite similar: thick ground with gesso grosso and gesso matte differentiation, yellow-reddish layers of bole, metallic alloy leaf, varnish or particulate deposits or residues of the "wax-resin" treatments (for the complex in MNAA). The overall composition of ground and bole layers in the both complexes is very similar as well: gypsum and animal glue in the grounds; clay minerals and ( $\mathrm{Fe}, \mathrm{Ti}$ )-oxides mixed with rabbit glue in the bole. Water gilding technique can be thus identified, the gold leaf being burnished on the surface to increase the brilliant appearance by light reflection.

As far as the composition of the leaf is concerned, the analysis detected the presence of a relatively thick leaf ( $5 \mu \mathrm{m}$ for MNAA and $10 \mu \mathrm{m}$ for VF respectively) made of an alloy $\mathrm{Au} / \mathrm{Ag} /$ 
A comparative interdisciplinary study of gilding techniques and materials in two Portuguese Baroque "talha dourada" complexes

I.C.A. Sandu, E. Murta, E. R. Neves, M.F.C. Pereira, A. V. Sandu, S. Kuckova, A. Maurício

$\mathrm{Cu}$ in different ratios, with a relatively high content of Au (21 carat gold for MNAA samples and 23 carat gold for VF samples) confirming data already reported in the literature about "gilding" materials on the territory of Portugal. The thickness of the leaf is slightly variable and this can point on a different quality of the gilding layer application between the church in Lisbon and the rural one or better skills to laminate the gold leaf (in this respect economic issues can be considered as reason for the use of a thicker leaf for the second case against the thinner leaf in the first case). The organic materials that were successfully identified are the animal glue in the preparative layers (ground and bole) and coatings based on tri-glyceridic materials (wax) in case of samples from Vale de Figueira church (it seems there was a local practice for varnishing the gold leaf with wax).

The micro-architecture investigated through micro-CT and SEM techniques showed different characteristics for the two complexes: MNAA samples display a ground with a relatively homogenous granulometry and sporadic porosity (big pores or holes can be detected within the structure) and with discontinuities due to fissures or small lacunae in the surface layers. The samples from VF (especially VF7) display a ground with heterogeneous porosity (big pores and also small, diffused ones), the gold leaf is continuous (sample VF3) and adherent to the substrate (bole layers). SEM images for both stratigraphical structures show clearly different morphological and size dimension characteristics between the ground layer and the bole, which are much thinner than the gypsum (presenting long shaped slender crystals).

The conservation state of the polychrome gilded layers is generally good, no major alterations or degradations could be observed on the surface or at the interfaces between layers in the stratigraphical structures. The conclusions of the restorer about the effectiveness of the wax-resin consolidation methodology applied on "talha" from MNAA, was that the surfaces are greatly favoured by this treatment, the preparation and gilded layers being nourished, consolidated and integrated, the final aspect becoming denser and with colour depth, and were confirmed by the analytical data.

The novel, complementary approach to the study of these two complexes showed a high potential for diagnosis and mapping enabling to better assess multi-scale and multi-level information on the compositional, micro-structural and conservative aspects of these important assets from the Portuguese cultural heritage.

\section{Aknowledgements}

This work has been supported by Fundação para a Ciência e a Tecnologia through grants no. PEst-C/EQB/LA0006/2011, no. PEst-OE/CTE/UI0098/2011 and no. PTDC/EAT-EAT/116700/2010 and by FEDER Funds through Programa Operacional Factores de Competitividade - COMPETE. We would also like to thank to Dr. Nuno Leal (researcher at FCT-UNL, Portugal) for the assistance during sampling phase at the Church of Vale de Figueira and to Dr. Stephan 
A comparative interdisciplinary study of gilding techniques and materials in two Portuguese Baroque "talha dourada" complexes

I.C.A. Sandu, E. Murta, E. R. Neves, M.F.C. Pereira, A. V. Sandu, S. Kuckova, A. Maurício

Schäfer (HTTP://WWW.STEPHAN-SCHAFER.COM) for kindly providing access and information about the fluorescent stain.

\section{References}

[1] R. Smith, A Talha em Portugal, Lisboa, Livros Horizonte, 1962.

[2] S. Ferreira, A Talha - Esplendores de um Passado ainda Presente. Lisboa: Nova Terra, Colecção Arte nas Igrejas de Lisboa, N.o 1, 2008.

[3] AA. VV, A Escultura Policromada Religiosa dos Sec XVII e XVIII - Estudo comparativo de técnicas, alterações e conservação em Portugal, Espanha e Bélgica, in Actas do Congresso Internacional, Lisboa 29, 30 e 31 de Outubro de 2002, Instituto Português de Conservação e Restauro, Lisboa, 2002.

[4] N. Ferreira Alves Marinho, A Arte da talha no Porto na época Barroca (artistas e clientela, materiais e técnicas). Porto: CMP, Divisão de Museus - Património Histórico e Artístico, 1986, pp. 188- 204.

[5] A. Bidarra, J. Coroado, F. Rocha, Contributos para o estudo da folha de ouro de retábulos Barrocos por microscopia óptica e electrónica, Ge-conservacion/conservação no. 1, 2010, pp.183-191.

[6] A. Bidarra, J. Coroado, F. Rocha, An approach to the study of gold leaf from a Baroque altarpiece, Sculpture, polychromy and architectural decoration group, ICOM-CC, Triennium 2008-2011, Newsletter 2, October 2010, pp.9-11.

[7] A. Bidarra, J. Coroado, F. Rocha, Gold leaf analysis of three baroque altarpieces from Porto, ArchéoSciences, Revue d'archéometrie, 33, 2009, pp.417-421.

[8] A. le Gac, A.I. Seruya, M. Lefftz, A. Alarcão, The main altarpiece of the Old Catedral of Cimbra (Portugal), Characterization of gold alloys used for gilding from 1500 to 1900, 33, pp.423-432, 2009.

[9] E. Murta, A. Barreiro, Percursos na Escultura, uma experiência em conservação e restauro, alguns casos, in Colóquio Internacional de História de Arte, A Escultura em Portugal - Da idade média ao início da idade contemporânea: história e património, Palácio Fronteira, Lisboa, 2009.

[10] A. I. Seruya, et al. (dir.), Igreja da Madre de Deus. História, Conservação e Restauro, Museu Nacional da Azulejo, IPM, Lisboa, 2002.

[11] J. L. Porfírio, (coord.), O Museu Nacional de Arte Antiga Lisboa, IPM, Electra, 1994.

[12] E. Murta, O uso da cera-resina em tratamentos de conservação de superfícies douradas, in Actas da II Jornadas ARP, Lisboa, 29 a 30 de Maio 2009, pp. 43-55. 
A comparative interdisciplinary study of gilding techniques and materials in two Portuguese Baroque "talha dourada" complexes

I.C.A. Sandu, E. Murta, E. R. Neves, M.F.C. Pereira, A. V. Sandu, S. Kuckova, A. Maurício

[13] E. Murta, The use of wax-resin in conservation treatments of gilded surfaces, in e-conservation online magazine, 2009, Issue no 11. (HTTP://WWW.E-CONSERVATIONLINE.COM/ CONTENT/VIEW/794).

[14] I.C.A. Sandu, L.U. Afonso, E. Murta, M.H. de Sa, Gilding Techniques in Religious Art Between East and West, 14th -18th Centuries, in International Journal of Conservation Science, Volume 1, Issue 1, March 2010, pp. 47-62.

[15] A. Le Gac, A utilização de compostos á base de cera na escultura policromada dos séculos XVII e XVIII em Portugal, in Imagem Brasileira, no. 3, Actas do III Congresso do Centro de Estudos da Imaginária Brasileira, Minas Gerais, CEIB, 2006.

[16] A. Le Gac, First critical study in gilded raised decorations from Portuguese polychrome sculptures of the Eighteenth Century, Polychrome Skulptur in Europa-Technologie, Konservierung, Restaurierung. Acts of the International Congress of Polychrome Sculpture, Dresden School of Fine Arts, November 11-13, 69-76, 1999.

[17] G. Buccolieri, A. Buccolieri, S. Bracci, F. Carnevale, F. Falletti, G. Palam, R. Cesareo, A. Castellano, Gold leaf in 14th century Florentine painting, ArchéoSciences, Revue d'archéometrie, 33, 2009, pp.409-415.

[18] D. Bigelow, Gilded wood: conservation and history, Postprints of the Gilding Conservation Symposium, Philadelphia Museum of Art, October 1988. Madison, Connecticut: Sound View Press, p. 79-86, 1991.

[19] AA. VV, Studies in Conservation, 1970, Volume 15 - Number 4, November 1970: Special Issue on the Conservation, Technique and Examination of Polychrome sculpture;

[20] I.C.A. Sandu, S. Bracci, I. Sandu, M. Lobefaro, Integrated analytical Study for the authentication of five Russian icons (XVI-XVII centuries), Microscopy Research and Technique, 2009, 72: 755-765;

[21] S. Dumazet, A. Genty, A. Zymla, F.X. De Contecin, A. Texier, N. Ruscassier, B. Bonnet, $P$. Callet, Influence of the substrate colour on the visual appearance of gilded sculptures, in Proceedings of the XXI International CIPA Symposium, 01-06 September2007, Athens, Greece, 2007.

[22] AA. VV., Scientific Examination for the Investigation of Paintings: A Handbook for Conservators-restorers, D. Pinna, M. Galleotti, R. Mazzeo (eds), ISBN: 978-88-7038-474-1, 2009.

[23] E. Van de Casteele, S. Bugani, V. Van der Linden, K. Janssens, 2008, X-ray microtomography as an imaging tool in cultural heritage studies, in 9th International Conference on NDT of Art, Jerusalem, Israel, 25-30 May 2008.

[24] F. Casali, X-ray Neutron Digital Radiography and Computed Tomography for Cultural Heritage, in Physical Techniques in the Study of Art, Archaeology and Cultural Heritage, edited by D. Bradley and D. Creagh, 2006, Elsevier B.V., pp. 41-123. 
A comparative interdisciplinary study of gilding techniques and materials in two Portuguese Baroque "talha dourada" complexes

I.C.A. Sandu, E. Murta, E. R. Neves, M.F.C. Pereira, A. V. Sandu, S. Kuckova, A. Maurício

[25] P. Jacobs, V. Cnudde, Can X-ray computed tomography contribute to cultural heritage and stone conservation through the non-destructive monitoring of deterioration and restoration processes?, in Cultural Heritage Conservation and Environmental Impact Assessment by Non-destructive Testing and Micro-Analysis, Van Grieken and Janssens (eds), A.A. Balkema Publishers, Taylor and Francis Group, London, ISBN 905809681 5, 2005, pp.117-126.

[26] I.C.A. Sandu, M.H de SA, M. Costa Pereira, Ancient "gilded" art-objects from European cultural heritage: a review on different scales of characterization, in Surface and Interface Analysis, Special Issue dedicated to Cultural Heritage, 43, no. 8/August 2011, pp. 1134-1151.

[27] I.C.A. Sandu, T. Busani, M. H. de Sá, The surface behavior of gilding layers imitations on polychrome artifacts of cultural heritage, in Surface and Interface Analysis, Special Issue dedicated to Cultural Heritage, 43, no. 8/August 2011, pp. 1171-1181.

[28] I.C.A. Sandu, A.C.A. Roque, P. Matteini, S. Schäfer, G. Agati, C. Ribeiro Correia, J. Fortio Fernandes Pacheco, 2012, Fluorescence recognition of proteinaceous binders in works of art by a novel integrated system of investigation, in Microsc Res Techniq, Vol. 75, Issue 3, pp. 316-324, March 2012.

[29] I.C.A. Sandu, A.C.A. Roque, S. Kuckova, S. Schaefer, R. J. Carreira, The Biochemistry and Artistic studies: a novel integrated approach to the identification of organic binders in polychrome artifacts, in ECR - Estudos de conservação e restauro, vol.01, no.1, winter 2009, p.39-56.

[30] M. Strohalm, D. Kavan, P. Novaḱ, M. Volný, V. Havlícek, mMass 3: A Cross-Platform Software Environment for Precise Analysis of Mass Spectrometric Data. Anal. Chem. 2010, $82,4648$.

[31] M. Strohalm, M. Hassman, B. Kosata, M. Kodicek, mMass data miner: an open source alternative for mass spectrometric data analysis. Rapid Commun. Mass Spectrom.2008, 22, 905.

[32] S. Kuckova, R. Hynek, M. Kodicek, Identification of proteinaceous binders used in artworks by MALDI-TOF mass spectrometry, in Anal Bioanal Chem, 2007, 388:201-206.

[33] M. Derrick, D. Stulik, Landry, IR spectroscopy in Conservation Science, The Getty Conservation Institute, Los Angeles, 1999.

[34] I. Adrover Garcia, Applicazioni Della spettrofotometria IR allo Studio dei beni culturali, Collana I Talenti, I Prato, 2001.

[35] C. Nodal Monar, A. Calvo Manuel, Las técnicas de policromía barroca del noroeste de Portugal en los contratos y los tratados pictóricos, in S. Kroustallis et al. (Ed), Art Technology. Sources and Methods, Archetype Publications, 2008, London, pp.85-87.

[36] S. Santos Gomez, M. San Andres Moya, A. Rodriguez., Contribution to the study of grounds for panel painting of the Spanish School (15th - 16th centuries), in Proceedings Painting Techniques. History, Materials and Studio Practice, 2008, pp. 115-120 
A comparative interdisciplinary study of gilding techniques and materials in two Portuguese Baroque "talha dourada" complexes

I.C.A. Sandu, E. Murta, E. R. Neves, M.F.C. Pereira, A. V. Sandu, S. Kuckova, A. Maurício

[37] S. Santos Gomez, M. San Andres Moya, A. Rodriguez, Reconstruction of documented preparation methods for gesso grosso and gesso sottile in Spanish School panel paintings, in S. Kroustallis et al. (Ed), Art Technology. Sources and Methods, Archetype Publications, 2008, London, pp. 178-181.

[38] HTTP://SITES.FCT.UNL.PT/GILT-TELLER.

\section{Author's curriculum vitae}

Dr. Irina Crina Anca Sandu is a Conservation Scientist with 16 years of experience ( 8 of post-doctoral activity) in the field of investigation, diagnosis and authentication of cultural heritage. She is author or co-author of 12 monographs, 2 book-chapters, more than 50 papers in peer-reviewed journals and conference proceedings.

Since the period of her university studies she has been involved in research projects and international collaborations dealing with movable and immovable heritage. Among the most relevant results as Principal Investigator or member of the working group it can be mentioned the following: 3 projects of scientific investigation funded by Portuguese bodies; 1 Archlab Access grant within CHARISMA international project funded by the European Community (FP7 programme); 2 international projects, LabSTECH and EU-ARTECH, funded by the European Community (FP5-6 programmes); 9 research projects, funded by the Romanian Ministry of Research and Technology; 1 UNESCO project 536/ROM/70 for the Restoration of Probota Monastery (XVIth century Monastery in the list of UNESCO Cultural Heritage) financed by Japan Trust Fund, Romania; other collaborations with cultural institutions in the field of conservation in Italy (Association „I BASTIONI", Florence and Association "ICONE: Ricerca e Conoscenza", Biella) and Portugal (Institute for Museums and Conservation, Lisbon). Shi is the coordinator of the project Gilt-Teller: um estudo interdisciplinar multi-escala das técnicas e dos materiais de douramento em Portugal, 1500-1800" (PTDC/EAT-EAT/116700/2010) funded by FCT-MEC in Portugal.

Contacto: IRINA.SANDU@FCT.UNL.PT

Dr. Elsa Murta received a Bachelor in Conservation and Restoration of polychrome sculptures at the Instituto de José de Figueiredo, in Lisbon, in 1986. In 2011 she got a Master Degree in Decorative Arts by the Catholic University of Portugal with a specialization on gilded wood decoration ("talha dourada"). Currently she is developing a Ph.D. degree at the University of Lisbon, studying the influence of the Flemish art in the Portuguese sculpture between the 16th and 17th centuries, on the collection of the Museum of Ancient Art in Lisbon.

Her professional career began in 1984, with the curricular internship as conservator restorer in the Division of Sculpture of the Institute of José de Figueiredo, where she currently is coordinator of the division of conservation and restoration of sculpture in polychrome wood support and tutorials curricular internship students from national and foreign universities. 
A comparative interdisciplinary study of gilding techniques and materials in two Portuguese Baroque "talha dourada" complexes

I.C.A. Sandu, E. Murta, E. R. Neves, M.F.C. Pereira, A. V. Sandu, S. Kuckova, A. Maurício

She participates regularly on seminars, congresses and lectures in the field of conservation and restoration of polychrome sculpture and arquitectural decoration and is author of 16 written papers, either individual or in co-authorship published in peer reviews, chapter of books, preprints and post prints of congresses in the field of her specialization, the conservation and restoration of polychrome sculpture.

Contacto: ELSA.MURTA@GMAIL.COM

Dr. Eva Raquel Neves is responsible for the Cultural Heritage sector of Santarem Diocesis, being a graduate in Conservation and Restoration (pre-Bologna bachelor) from the Department of Conservation of the Faculty of Sciences and Technology of the New University of Lisbon, with a specialization in graphic documents (2001-2006). As academic training, she developed the research work "Antifungal effect of different methyl and propyl paraben mixtures on the treatment of paper biodeterioration", published in International Biodeterioration \& Biodegradation.

Since 2007, she is coordinator of the Patrimony's Inventory, Diagnosis and Valorization Project in Santarem Diocesis. She is also responsible, with P. Joaquim Ganhão, for publishing Church of Our Lady of Mercy of Santarem - History and Heritage, (2008) and the exposition and catalogue alluding to the theme: Santarém in India. D. Antonio Pedro da Costa, First Bishop of Daman (2009). She is collaborating as consultant in various tasks of the project Gilt-Teller: um estudo interdisciplinar multi-escala das técnicas e dos materiais de douramento em Portugal, 1500-1800" (PTDC/EAT-EAT/116700/2010) funded by FCT-MEC in Portugal.

Contacto: EVARAQ@gmaIL.com

Dr. Manuel Pereira is a Geoscience Scientist and Professor with 22 years of experience (7 of post-doctoral activity) in several fields of investigation, mainly evolving the physical and chemical characterization of natural materials.

Manuel Pereira earned the degree in Geochemistry from the University of Aveiro (Portugal) in 1995 and a PhD in Mining Engineering from the Technical University of Lisbon (Portugal) in 2005. As Assistant Professor at the Superior Technical Institute (IST) of the Technical University of Lisbon and member of the Centre for Petrology and Geochemistry (CEPGIST) he is involved in different research R\&D projects (namely DECASTONE - dealing with monument stone decay studies and geotechnical applications). He is co-responsible for the Laboratory of Mineralogy and Petrology of IST and also Director of the Geosciences Museums and Archive. Is also a member of the IST Scientific Platforms of Environment and Nanomaterials.

Since 2000 he is collaborating within several projects from the area of cultural heritage conservation, applying analytical techniques such as Optical Microscopy, XRD, XRF, ATD-TG, non-destructive 3D X-ray microtomography, FTIR to the characterization of artistic (pigments, inerts, metal leaves), biological (human, animal and vegetable materials) and 
A comparative interdisciplinary study of gilding techniques and materials in two Portuguese Baroque "talha dourada" complexes

I.C.A. Sandu, E. Murta, E. R. Neves, M.F.C. Pereira, A. V. Sandu, S. Kuckova, A. Maurício

building (cements, mortars, polymers) materials. He is also dealing with management and curatorship tasks for museums and collections in Geological field, organizing events within broader activities for dissemination of science to the specialized and larger public in Portugal (Ciência Viva, Rotas da Matemática, training programs for high school teachers in History).

Contacto: MFCP@IST.UTL.PT

Eng. Andrei Victor Sandu graduated from the "Gheorghe Asachi" Technical University of Iasi, Faculty of Materials Science and Engineering in 2007; in 2012 obtained a MSc in Advanced Analysis Techniques and currently is doing a PhD in Material Science. He is specialized in advanced analytical techniques for material science and art /archeological objects characterization. He has published more than 30 papers in ISI peer-reviewed International Journals, 20 articles in national journals and over 50 communications in International Conferences. He is also publishing editor of International Journal of Conservation Science (ISSN 2067-533X) and International Journal of Criminal Investigation (ISSN 2247-0271) and editor of some Conference Proceedings. Another branch of his research is focused on submitting patents, promoting and developing inventions, being the manager of Romanian Inventors Forum. In present is the coordinator of EUROINVENT - European Exhibition of Creativity and Innovation, largest conference of inventions in Romania. He is official delegate of Romania and member of the Jury at the following Invention exhibitions: British Invention Show London, ATTIC Barcelona, INOVA Zagreb, NEW TIMES Sevastopol and ARCHIMEDES Moscow.

Contacto: ANDREW_VIKTOR@YAHOO.COM

Dr. Stepanka Kuckova received the doctoral degree in 2006 and at the present is working at the Institute of Chemical Technology and Charles University where she has teaching undergraduate courses of analytical chemistry, biochemistry and application of chemical methods, seminars of biochemistry and analytical chemistry, laboratory work courses of analytical chemistry, biochemistry and instrumental analytical techniques. Since 2001 she is member of the Czech Chemical Society and since 2010 member of MaSC group. She has experiences in application of analytical chemistry and biochemistry in the field of cultural heritage. She developed a completely new technique for unambiguous and fast identification of proteinaceous binders in colour layers of artworks using peptide mass mapping. Her scientific activities can be summarized in 3 book-chapters and more than 30 papers in peer-reviewed international journals and conference proceedings. She presented over 40 oral contributions and posters at scientific conferences till now.

Contacto: KUCKOVAS@VSCHT.CZ 
A comparative interdisciplinary study of gilding techniques and materials in two Portuguese Baroque "talha dourada" complexes

I.C.A. Sandu, E. Murta, E. R. Neves, M.F.C. Pereira, A. V. Sandu, S. Kuckova, A. Maurício

Prof. António Maurício is a Geoscience Scientist and Professor with about 31 years of experience (18 of post-doctoral activity) in several fields of investigation, mainly involving Water-Rock Interaction in Meteoric-Environments; Cultural Heritage-Environmentally-induced natural materials decay diagnosis and control; 2D Image and Data Analysis and more recently X-Ray Micro-tomography (3D microscopy).

António Maurício was Mining Engineer-IST graduated (5 years) in 1982; post-graduated in Mining MsE - Mineralogy and Mining Planning - IST (3 years) in 1986, and PhD. Mining Engineering - IST in 1994 from Technical University of Lisbon - IST (Portugal). As an Associate Professor with tenure since 2001 at Lisbon Superior Technical Institute (IST) and member of the Centre for Petrology and Geochemistry (CEPGIST) he is involved in different research R\&D projects (namely DECASTONE - dealing with water-rock interaction geochemistry, monument stone decay studies and geotechnical applications). He supervised and was part of jury of students in integrated Masters, Masters students (now 2nd cycle) and PhD students (current 3rd cycle), in national and of foreign universities. He is author of more than 70 publications in peer-reviewed scientific journals, proceeding of conferences, books, etc.

Contacto: PCD2045@IST.UTL.PT 